\title{
Actitudes hacia la química de los estudiantes de biología: una reflexión sobre su evolución desde química general e inorgánica a química biológica
}

\author{
Reyes, María S.; ${ }^{1}$ Porro, S. ${ }^{2}$
}

Recibido: 07/10/2016

Aprobado: 08/11/2016

\section{Resumen}

En el presente artículo se reflexiona sobre la importancia de la dimensión afectiva en el proceso de enseñanza-aprendizaje de las ciencias experimentales en general y de la química en particular. Se describen las actitudes hacia la química de los estudiantes de las carreras de Licenciatura en Biodiversidad y Profesorado en Biología de la

Universidad Nacional del Litoral, analizando las mismas en tres cursos de química:

Química General e Inorgánica, Química Orgánica y Química Biológica. Poniéndose de manifiesto que en aquellas asignaturas donde los estudiantes se sienten más motivados con los contenidos de la cátedra o bien los consideran más afines y cercanos con su formación profesional, sus actitudes evolucionan favorablemente observándose también una mejora en el rendimiento académico.

Palabras clave: actitud, química, estudiantes de biología.

\footnotetext{
${ }^{1}$ Cátedra de Química General e Inorgánica. Facultad de Humanidades y Ciencias. 


\section{Summary}

In this article we reflect on the importance of the emotional dimension in the teachinglearning process of experimental science in general and chemistry in particular. The attitudes toward chemistry of students of Licenciatura en Biodiversidad and Profesorado en Biología of Universidad Nacional del Litoral are described, analyzing them in three chemistry courses: General and Inorganic Chemistry, Organic Chemistry and Biological Chemistry. Manifesting themselves in those subjects where students are more motivated with the contents or consider them more akin and near with their training, their attitudes evolve favorably also observed an improvement in academic performan.

Keywords: attitude, chemistry, biology students. 